\title{
The Integration of Intercultural Business Communication Training and Business English Teaching
}

\author{
Deng Jingzi ${ }^{1}$, Zhu Wenzhong ${ }^{2} \&$ Elizabeth Elendor Dimond ${ }^{3}$ \\ ${ }^{1}$ School of English for International Business, Guangdong University of Foreign Studies, Guangzhou, China; \\ School of Humanities and Social Sciences, National University of Defense Technology, Changsha, China \\ ${ }^{2}$ School of Business and School of English for International Business, Guangdong University of Foreign Studies, \\ Guangzhou, China \\ ${ }^{3}$ Foreign Affairs Office, National University of Defense Technology, Changsha, China \\ Correspondence: Deng Jingzi, School of English for International Business, Guangdong University of Foreign \\ Studies, Guangzhou, China. Tel: 86-13787110851. E-mail: Christina519@163.com
}

\author{
Received: November 14, 2015 Accepted: January 5, 2016 Online Published: January 7, 2016 \\ doi:10.5539/elt.v9n2p77 URL: http://dx.doi.org/10.5539/elt.v9n2p77
}

\begin{abstract}
The cultural information transferred by language is an important part of Business English teaching. Therefore, teachers of Business English should not only improve the language level of the students, but also develop the students' cross-cultural understanding. The cultivation of intercultural business communication (IBC) competence could not be realized by one or several courses, it must be emphasized through the entirety of Business English teaching. For example, elements of intercultural training should be reflected in Business English teaching materials, classroom discourse, teaching activities, and teaching methodology. This paper analyzed the afore-mentioned elements of IBC competence. Utilizing literature reviews and questionnaires, it also revealed problems in teaching and cultivating IBC competence in Business English curriculum and examined what obstacle Chinese students experience in intercultural communication. The author of this paper proposed three principles that should be followed while integrating IBC competence and Business English teaching in order to realize the simultaneous increase of course knowledge and IBC competence, and to further students' professional knowledge, English language ability, and intercultural business fluency.
\end{abstract}

Keywords: intercultural business communication (IBC) competence, Business English teaching, the cultivation goals of Business English talents, integrated teaching methods

\section{Introduction}

In China, there is a saying “一方水土, 一方人”, which literally reads as “one place, one people," with the meaning that people from different places will possess characteristics based on where they come from. These local characteristics represent different cultures. Fang (2003:109) thought different cultures refer to unique cultural traditions, identities, and development histories which differ between nationalities, regions, and countries. In cross-cultural exchanges, foreign language learners will find that their foreign language communication ability will face tremendous challenges; their native culture's communication practices and thinking methods will not always translate, often leading to misunderstandings and censure. General pragmatic competence (communication competence) is lacking without additional intercultural communication knowledge. Therefore, intercultural communication competence is critical (Bi, 2014).

Through economic globalization, international business exchanges are becoming increasingly frequent. Global economic activities are increasingly being impacted by the intercultural communication competence of today's businessmen and women. Therefore, we need to broaden the cultivation of intercultural fluency in business education programs. The main objective of Business English schools should be to build an intercultural communication bridge between foreign cultures and Chinese cultures and develop students' competence in intercultural business communication (IBC).

In short, due to the importance of intercultural communication competence in international exchanges, Business English students need to improve their cultural awareness and cultural adaptations. However, developing curriculum that increases the understanding of foreign cultures is a big task for Business English teachers in 
China. This paper hypothesizes that currently, there are problems in Chinese business cultural education. This paper utilizes a literature review and a survey in order to examine the problems in current IBC training in Business English education and the reasons leading to these problems. The collected evidence proves the validity of this paper's stated hypothesis. Finally, this paper will explore potential teaching methods and principles which can help teachers to improve the quality of cultural education in English language learning.

The author of the paper has stressed that the cultivation of IBC must be emphasized throughout the entirety of the Business English teaching process. This can be realized through putting greater teaching emphasis on course knowledge goals, producing well rounded students with professional business knowledge improving English language skills, and IBC competence.

\section{Literature review}

\subsection{Communication competence}

In the 1970s, Hymes (1971) first proposed the concept of Communication Competence. It initiated a teaching revolution in language educational circles and made language teachers realize that they shoulder the responsibility of cultivating active language users - not passive grammarians (Hall, 1976). In particular, communication competence has four describing parameters: it is possible in the form, it is feasible in the way, it is appropriate in the context, and it is finished in the action and it contains different meanings. We can redefine these four parameters' connotations into four kinds of knowledge and abilities: grammatical knowledge and ability; psycholinguistic knowledge and ability, socio-cultural knowledge and ability, and practical knowledge and ability.

\subsection{IBC competence}

Internationally, there is a wide array of research findings on intercultural communication competence. Hall (1990) acknowledged that intercultural communication competence can be defined as a unique manner possessed by an individual who wants to realize his character, goals, and expectations in a specific environment. Language communication is carried out in a specific context and the use of language is changed by different communication functions

Clair (1991) proposed "three communication principles": learn to look at things, experience things and understand the world from the other side. In business communication, the essence of these three communication principles is reflected in the language users' intercultural communication competence.

Johnson and Apud (2006) define intercultural competence in international business as: "an individual's effectiveness in drawing upon a set of knowledge, skills, and personal attributes in order to work successfully with people from different national cultural backgrounds at home or abroad".

Gudykunst and Kim (1997) proposed that intercultural communication competence includes affective competence, cognitive competence, and behavior competence. They connect with each other, influence each other, and depend on each other. Intercultural competence becomes more sophisticated for cross-cultural properties in communication. Most scholars focus on three aspects of cognition, affection, and behavior. It fully demonstrates that cognition, affection, and behavior are key factors in communication competence. In recent years, Chinese scholars have published a large number of books and papers on the relationship between language and culture as well as cultural teaching. Wang, Chen, and Ge (2013) conducted detailed research on IBC. Their findings indicated that IBC consists of three parts: business strategy, communication strategy, and cross-cultural strategy. They interact with each other to form a dynamic and changing system.

Xu and Guo (2012) explained cognitive competence, affective competence, and behavioral competence in detail. Cognitive competence refers to individuals having communication skills, professional knowledge of the international trade system, and business operation skills. They can correctly understand and utilize international business rules. They can also use business thinking to solve problems in business communication. Affective competence refers to empathy. In cross-cultural activities, communicators need to free themselves from the influence of their native cultures, understand and master different cultures' characteristics and thinking modes, find overlapping parts among different cultures, and ensure smooth cross-cultural business communication. Behavior competence includes language competence and non-language competence as it refers to a practical ability to solve problems in communication by using cross-cultural knowledge. For IBC subjects, language competence and non-language competence in business and cross-culture communication are a guarantee of successful IBC.

In summary, the cultivation of IBC is a long and complicated process. Culture, business, communication, language, and other aspects must be incorporated throughout the entirety of the teaching process. Most Business 
English courses need to be taught in an intercultural manner. Furthermore, concepts and meanings of IBC competence need to be set as principles and standards of Business English teaching, integrating cross-cultural teaching theories with Business English teaching practices.

\section{Problems in Chinese Business English Teaching}

"National Criterion for BA Programs in Business English of China" points out that major aims of university Business English's programs in China are to cultivate multi-talented students who have mastered basic knowledge and theories of economics, management, law and other related subjects; and who possess high level intercultural communication competence (Chen \& Wang, 2009). The Business English talent objectives published by the Chinese government made many Chinese universities realize the importance of cross-cultural knowledge in Business English teaching. However, the cultivation of students' IBC competence is a comprehensive and sophisticated teaching task that is only now starting to be addressed by Chinese Business Schools. This area is still in the initial stages of becoming a teaching subject, particularly course matter on how to integrate intercultural teaching theories with practical training; how to build a lifelike international business environment in the classroom, and how to gradually improve students' IBC ability. Teaching and research on this subject are in an exploration stage. Cao (2012) once wrote that in the foreign language world, some universities and departments have opened intercultural communication courses, but these courses place emphasis on intercultural communication at the interpersonal level and seldom focus on intercultural communication at the organizational level.

Liu and Liu (2014) designed a questionnaire relating to IBC competence and distributed it to 90 Business English graduates who engaged in international business in 30 separate enterprises in 10 separate cities. The results show that the graduates suffered from problems associated with limited language ability, lack of cross-cultural consciousness, and limited cross-cultural knowledge. Graduates could not define their interests effectively when encountering conflicts in negotiations and couldn't use appropriate language to naturally communicate with customers. The majority of the graduates never considered solving problems from a cultural angle and usually used their own cultural values and principles as judgment. Furthermore, the graduates lacked a necessary understanding of their foreign business partners' business etiquette and business decision making habits and failed to target their partners' cultural values. In conclusion, the graduates felt deeply worried about their lack of IBC competence.

Zhao (2013)'s survey of 35 Business English teachers from Hebei local Normal Universities shows that $66 \%$ of the teachers were not sensitive to target language culture and $72 \%$ of the teachers generally felt a lack of intercultural competence. In a survey on teachers' understanding of their native (Chinese) culture, $75 \%$ of the teachers didn't fully understand Chinese culture and customs, which directly affects students' development of intercultural understanding. In addition, Business English teachers put too much emphasis on the cultivation of students' English competence and Business knowledge. They set the Business English Certificate issued by Cambridge University and other business related certificates as the teaching objective. The socio-cultural elements of languages and the cultural characteristics and values behind business activities are often overlooked by teachers (Chen, 2007).

Therefore, in order to educate qualified IBC talents, a teaching system which includes intercultural understanding, business, and communication in its content needs to be constructed. Teachers need to constantly improve their cultural appreciation and consciousness towards target languages' countries of origin and encourage their students to do the same. Jia (1997) in his book "Intercultural Communication" pointed out that the ultimate goal of foreign language education is to cultivate intercultural communication competence and that language teaching, to a large extent, should be cultural education. The cultivation of intercultural communication competence should be emphasized throughout the entirety of Business English teaching and elements of intercultural training and should be reflected in Business English teaching materials, classroom discourse, teaching activities, and teaching methodology.

\section{Reasons for Intercultural Communication Barriers That Develop During Chinese Students' Business English Learning}

Let us discuss the problems leading to Chinese students' IBC deficiencies.

\subsection{Business English Textbooks Seldom Reflect or Emphasize Cultural Elements}

General English teaching emphasizes grammatical training to strengthen students' language ability. This is reflected in traditional Business English teaching methods: teachers play a dominant role, but the central focus is on the students. The teaching structure operates according to teaching materials and exam requirements. This 
structure often ignores the development of IBC competence as a teaching objective. In order to illustrate this problem, in 2014 the author of this paper distributed a questionnaire survey to Business English undergraduate students, classrooms 1 to 4, from Guangdong University of Foreign Studies at the end of their term (year). 198 students participated in the survey, and 190 valid questionnaires were collected. The questionnaire is divided into Table 1 and Table 2. Table 1 aims to examine adult students' understanding of the relationship between Business English learning and culture. Table 2 shows students' overall attitudes towards teaching materials. Table 2 used SPSS 19.0 for the statistical analysis. This survey was originally distributed in Chinese and it has been translated into English for the purpose of this paper.

Table 1. Questionnaire Survey

\begin{tabular}{lllll}
\hline Questions & Choices & & \\
\hline $\begin{array}{l}\text { What supplementary text materials do you use the } \\
\text { most in your Business English courses? }\end{array}$ & $\begin{array}{l}\text { Teachers' } \\
\text { notes }\end{array}$ & $\begin{array}{l}\text { lectures } \\
\text { Business } \\
\text { newspapers } \\
\text { articles }\end{array}$ & $\begin{array}{l}\text { Cultural } \\
\text { lead-in } \\
\text { knowledge }\end{array}$ \\
\hline $\begin{array}{l}\text { Does intercultural knowledge occupy a large part in } \\
\text { your present Business English textbooks? }\end{array}$ & No & Few & Many \\
\hline $\begin{array}{l}\text { Is intercultural knowledge important in business } \\
\text { exchanges? }\end{array}$ & Not too important & important & $\begin{array}{l}\text { Very } \\
\text { important }\end{array}$ \\
\hline $\begin{array}{l}\text { Which methods do you employ in learning Business } \\
\text { English? }\end{array}$ & $\begin{array}{l}\text { Repeatedly } \\
\text { and copy }\end{array}$ & recite & Memorize with business discourse \\
\hline $\begin{array}{l}\text { What do you expect to gain by learning Business } \\
\text { English? }\end{array}$ & $\begin{array}{l}\text { Have } \\
\text { memory }\end{array}$ & better & $\begin{array}{l}\text { Learn more cultural background } \\
\text { knowledge }\end{array}$ & \\
\hline
\end{tabular}

In Business English learning, what is your biggest challenge?

The results show that $70 \%$ of the students base that their Business English learning mainly on texts and teachers' knowledge. $74 \%$ of the students said that intercultural lead-in knowledge in textbooks is marginal. $30 \%$ of the students thought that intercultural knowledge is very important in cultural exchanges. $90 \%$ of the students still used repetition to learn Business English, and $56 \%$ of the students worried that the content they were learning would not be useful in future practical business activities.

After a survey on the students' attitudes towards intercultural knowledge and their methods of learning, the author wanted to further investigate their judgments on the teaching materials as show below in Table 2 .

Table 2. Teaching materials evaluation

What is your overall judgment on Business English materials currently being used?

A. Boring; B. Average C. Good; D. Very good.

\begin{tabular}{llllll}
\hline & & Frequency & Percent & Valid Percent & $\begin{array}{l}\text { Cumulative } \\
\text { Percent }\end{array}$ \\
\hline & A & 8 & & 3.1 & 3.1 \\
\hline & AB & 1 & .4 & .4 & 3.5 \\
\hline & B & 97 & 37.7 & 37.7 & 41.2 \\
& BC & 1 & .4 & .4 & 41.6 \\
& C & 126 & 49.0 & 49.0 & 90.6 \\
& CD & 3 & 1.2 & 1.2 & 91.8 \\
& D & 21 & 8.2 & 8.2 & 100 \\
\hline & Total & 257 & 100.0 & 100.0 & \\
\hline
\end{tabular}


$37.7 \%$ of the respondents thought materials to be average. $49 \%$ of the respondents thought the materials to be good, and $8.2 \%$ of the respondents thought the materials were very good. Through teacher-student forums and questionnaire surveys, we find that students are satisfied with the presently used "Experience Business English" books 3-4. However, the students also thought that textbooks were lacking in humanistic contents corresponding to the courses, and that few texts included cultural explanatory notes, which is not advantageous to students as these texts fail to provide relevant cultural knowledge.

The results from this survey provided the basis for this paper. Current teaching materials are lacking in cross-cultural lead-ins; most students don't have a clear understanding of the importance and function of intercultural knowledge in Business English learning; students of Business English are primarily learning by rote. All of these trends lead to language education being separate from cultural education in Chinese universities.

\subsection{Business English Teaching Modes are Affected by Traditional English Teaching}

Influenced by traditional English teaching styles, Business English teaching tends to focus on pronunciation, grammar, and vocabulary. The thought behinds this is, that if a student acquires pronunciation, grammar, and vocabulary, he has acquired language and communication. However, this theory doesn't apply to the training of Business English students who are supposed to be successful in the working world. Winston Brembeck once said, "Only teach the language and do not teach its culture. It is the best way to develop language fluency of the big fool" (Quoted from Luo \& Cai, 2011).

\subsection{The Lack of Intercultural Education Amongst Business English Teachers in China}

One of the reasons that Business English teachers in China lack intercultural education is because of the way they themselves were taught as students. For most Business English teachers, "Language skills, plus linguistic theories, plus pedagogies" (Zhou, 2005) is the basic frame of their knowledge structure. Secondly, Business English teachers in China lack opportunities to acquire intercultural teaching training. Presently, many Business English teachers are aware of their deficiencies in intercultural knowledge and are eager to improve their intercultural communication competence. However, due to workload, few foreign exchange opportunities, and lack of definite standards in teaching evaluations, it is difficult to improve intercultural education. Business English teachers in China have difficulties in taking steps to improve their intercultural education (Zhao, 2013).

\section{Principles for IBC Competence Cultivation in Chinese Business English Teaching}

The above problems and reasons that appear in Business English teaching require intervention which would improve students' cultural awareness in business. In the non-English context, we can choose better English original materials in order to better meld language, culture, and business rules. When taking Business English courses, students should not only master the usage of grammar rules, vocabulary, and sentence patterns, but also acquire cultural understanding for intercultural communication in business. Therefore, it is necessary to merge IBC competence training with Business English teaching. In order to do that, several effective teaching principles should be followed.

\subsection{Practicality Principle}

Business English is a subject which integrates language and professional knowledge, attaching great importance to practical application. Although Business English programs at some major universities have opened oral classes taught by foreign teachers, the course themes are typically restricted to limited lifestyle terms. This, to a certain extent, leads to students graduating from these programs still failing to meet the expected teaching objectives. In addition, in current Business English teaching, shortcomings of low quality course content with no unique features exist. Coursework is still oriented towards examinations, not real world ability. It is common to see students that memorize material simply to earn credits and read books only for examinations. This model cannot cultivate and endow students with the ability to be competitive in the international world. In an era of cultural and economic globalization, it is far too little; students need to be taught real world applications for the coursework covered. The principle of practicality requires that lead-in culture education should be closely linked with students' real language use. Business cultural knowledge taught by teachers should play a bridge role in students' business communication with native speakers instead of an isolated, memorization oriented method of teaching.

\subsection{Persistance Principle}

Persistence principle requires that the target culture should be introduced into teaching in a persistent, systematic, high-intensive, and gradual way. Teachers ought to use case methods and task-based teaching methods to help students systematically analyze the similarities and differences between mother tongue and native language structures and business cultures, so as to acquire a cultural sensitivity for IBC. After an introduction to the target 
culture's history, literature, allusions, and idioms, teachers guide students subconsciously to accept and understand target business culture. Certainly, this cultural introduction process is totally based on a student's language proficiency, understanding, and ability to decide to embrace the cultural teaching's content. By helping students to cultivate their understanding of the cultural backgrounds in business, we can take Business English courses from shallow to deep, from simple to complex, and from the phenomenon to the essence. Furthermore, this style of teaching helps achieve consistency in how students approach the subject.

\subsection{Combination Principle of Language Knowledge, Professional Knowledge and Cultural Introduction}

Learning professional knowledge and skills cannot be independently achieved through one specialized course, all courses should include aspects of professional skills and business knowledge. Cultural introduction should not be a specialized course. Grammar, text, vocabulary, listening materials, and extensive reading materials should all contain cultural content. Therefore, we need to combine language knowledge, professional knowledge, and cultural introduction together in order to form multi-channel joint teaching and finally, produce qualified IBC talents. In addition, Business English teachers need to address the standard educational concept of only teaching knowledge, social customs, and habits. Instead, they need to: establish the training concept of educating well-rounded students with intercultural ability; foster students' correct understanding of differences in cultures; help them overcome narrow national, racial, and regional outlooks and treat different cultures objectively and fairly so as to eventually become business talents with excellent cross-cultural communication skills.

\section{Conclusion}

The integration of IBC training and Business English teaching is a long-term systematic project. Therefore, in the process of educating well-rounded students in business English, Business English teachers should prioritize cultivating students' intercultural communication competence throughout teaching exercises. Firstly, teachers should pay attention to students' cultural perspectives and emotional needs. Secondly, teachers need to enrich teaching methods and teaching contents so as to arouse students' interests in cross-cultural communication. Thirdly, teachers need to guide students to explore new ways of expression in order to meet the emotional and cultural needs of the individual. Fourthly, teachers need to improve students' comprehensive quality and business ability so as to meet the growing need for international exchange. In conclusion, the teaching objective of intercultural communication is to develop international businessmen and women who will be able to succeed in international economic competition.

\section{Acknowledgement}

This research is supported by Guangdong University of Foreign Studies No.15GWCXXM - 06 (the Innovation Research Project for Graduate Students "The Construction and Research of Business English CMB Theory Model").

\section{Reference}

Bi, J. W. (2014). Cross-Cultural Communication and Second Language Teaching (p. 6). Beijing: Language and Culture University Press.

Cao, D. C. (2012). A Theoretical Framework for China's Business English Based on International Business Communication. Foreign Language in China, 9(3), 10-15.

Chen, H. B. (2007). The Emphasis of Inter-cultural Information in Business English Practical Teaching. Science and Technology, 36, 214, 256.

Chen, Z. M., \& Wang, L. F. (2009). Developing National Curriculum for BA Programs in Business English in China. Foreign Language in China, 6(4), 4-11, 21.

Clair, R. (1991). Directions in Sociolinguistics: The Ethnography of Communication (p. 122). Jersey City, New Jersey: Wiley-Blackwell.

Fan, H. W. (2003). Comparative Culturology (2nd ed., p. 109). Guilin, Guangxi: Guangxi Normal University Press.

Gao, J. C. (2011). A Study of Primary Chinese Teachers' Effective Classroom Discourse Characteristics Based on Classroom Observation. China Journals Books Network, 7, 93-96.

Gudykunst, W., \& Kim, Y. (1997). Communicating with Strangers: An Approach to Intercultural Communication (3rd ed., pp. 83-104). New York City, New York: McGraw -Hill.

Hall, E. (1976). Beyond Culture (p. 5). New York City, New York: Doubleday.

Hall, E. (1990). The Hidden Dimension (2nd ed., p. 13). New York, New York: Anchor. 
Hymes, D. (1972). On communicative competence. Sociolinguistics: Selected readings (pp. 269-293). Harmondsworth: Penguin.

Jia, Y. X. (1997). Intercultural Communication (p. 9). Shanghai: Shanghai Foreign Language Education Press.

Johnson, J., Lenartowicz, T., \& Apud, S. (2006). Cross-cultural competence in international business: Toward a definition and a model. Journal of International Business Studies, 2(37), 525-543-37, 525-543. http://dx.doi.org/10.1057/palgrave.jibs.8400205

Liu, Y. Q., \& Liu, Y. H. (2014). The Cultivation of College Business English Students' Intercultural Communicative Competence. Journal of Inner Mongolia Normal University (Educational Science), 27(9), $120-122$.

Luo, Y., \& Cai, H. P. (2011). English Classroom Teaching Strategies and Research Methods (p. 33). Wuhai, Hubei Province: Huazhong University of Science and Technology Press.

Wang, L. F., Chen, X. L., \& Ge, H. L. (2013). On the Theoretical Framework of Business English Linguistics. Contemporary Foreign Language Studies, 5, 25-31, 77.

Wilkins, D. (1972). Linguistics in Language Teaching (p. 54). Cambridge, Massachusetts: The MIT Press.

Xu, P., \& Guo, H. P. (2012). Composition and Training in Intercultural Business Communication Ability. Chinese Outside School Education, 3, 2-2.

Yan, M. (2009). The Construction of an Inter-Cultural Communicative Competence System. Hei Longjiang Social Sciences, 6, 130-133.

Zhao, X. L. (2013). The Study of Business English Intercultural Education from the Perspective of Intercultural Communication. Journal of Langfang Nornal College, 29(1), 111-114.

Zhou, Y. (2005). A Need's Investigation and Study of College's English Teachers' Development. Foreign Language and Their Teaching, 37(3), 206-210.

Zhu, J. C. (2009). Cultivating Students' Intercultural Competence to Train Global High-Quality Talents. Journal of UESTC (Social Sciences Edition), 11(2), 79-82.

\section{Copyrights}

Copyright for this article is retained by the author(s), with first publication rights granted to the journal.

This is an open-access article distributed under the terms and conditions of the Creative Commons Attribution license (http://creativecommons.org/licenses/by/3.0/). 